Tuberculosis
$\begin{aligned} & \text { Public-private } \\ & \text { consortium aims to } \\ & \text { discover new drugs } \\ & p 692\end{aligned}$

\title{
Feathers fly over Chinese fossil bird's legality and authenticity
}

San Diego

The US palaeontology community has been rocked by a Chinese 'bird' fossil that may be a new species, but that many suspect to be be a composite of more than one fossil that was smuggled illegally out of China.

The fossil was bought last year at an Arizona mineral show for $\$ 80,000$ on behalf of a small Utah museum. It has since been valued for insurance purposes at $\$ 1.6$ million, and has been heralded as an important link in dinosaur and bird evolution - in particular, in an article in National Geographic last autumn.

But Chinese scientists want the Utah museum to repatriate it immediately. And, in a move which has left the magazine deeply embarrassed, some palaeontologists are also saying that the fossil's tail may come from another specimen.

"This is a disaster for science," says Xu Xing, a graduate student at the Institute of Vertebrate Paleontology and Paleoanthropology in Beijing, who collaborated on a paper describing the fossil and has been involved in repatriation negotiations.

The fossil is believed to have come from the Liaoning area in northeast China, where many bird-like specimens dating from the Cretaceous period have been discovered.

An article in the November 1999 issue of National Geographic claims that the specimen is one of the "missing links in dinosaur evolution". But computerized tomography tests have shown that the fossil's tail may have been added in a bid to increase its black-market value. The magazine is to publish a note in its March issue stating that the specimen is "a composite", and that tests have "revealed anomalies in the fossil's construction".

In the November article, the magazine gave the specimen a name - Archaeoraptor liaoningensis - even though it had not been formally described in a peer-reviewed journal. This angered scientists such as Storrs Olson, curator of birds at the US National Museum of Natural History in Washington DC, who has described the move as "the worst nightmare of many zoologists".

Magazine officials say that the publication of the name and details of the fossil was a

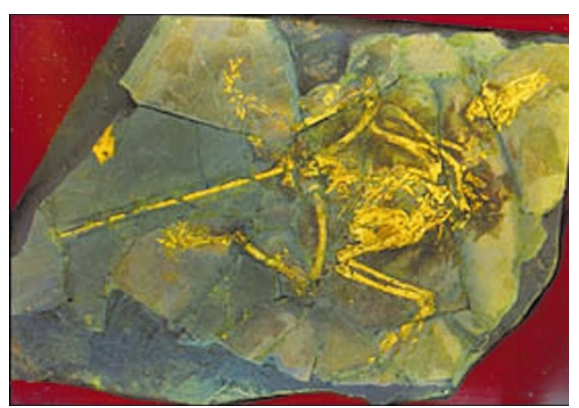

Dead duck? 'Archaeoraptor' may be the tail of a primitive bird stuck to the body of a dinosaur.

"mistake" that resulted from marketing efforts leapfrogging an unsuccessful bid for scientific publication - one of several miscues during the fossil's journey through America.

Bill Allen, National Geographic's editor, said in a letter to a scientist involved that he "was totally outraged" by what occurred, acknowledging that it has damaged the magazine's credibility. Chris Sloan, who wrote the fossil story, says that the magazine has now agreed not to publish the name of a specimen until a scientific journal has described it.

Exactly how the fossil left China is unknown, although $\mathrm{Xu}$ and other scientists insist it must have been smuggled out. Its trail in America begins in the autumn of 1998, when scientists gathered in a Utah ski resort for the annual meeting of the Society of Vertebrate Paleontology heard rumours of an exciting bird fossil available on the private market.

The fossil - which scientists now believe was the one featured in National Geographic - was offered for sale in February 1999 at the annual Gem, Mineral and Fossil Showcase of Tucson, Arizona, reportedly the world's largest gathering of fossil dealers.

The purchase of the fossil was organized by Stephen Czerkas, a self-educated dinosaur enthusiast and artist who runs the non-profit Dinosaur Museum in the small town of Blanding, Utah.

Czerkas convinced patrons of the Dinosaur Museum, including trustee Dale Slade, to put up $\$ 80,000$ to buy the specimen. Slade, a businessman who provides material for semiconductors, says that documents exist showing that the fossil is part of a museum exchange programme and was not smuggled; but he declined to make such records available to Nature.

Czerkas says that he bought the fossil to save it for science, planning to return it to China after display. Sloan says the fossil was to become "the crown jewel" in the Blanding museum, calling the facility "the brainchild" of Czerkas and his artist wife, Sylvia.

Sloan says that last spring, while working on his National Geographic article, he went to Utah and convinced Czerkas to repatriate the fossil, telling him the magazine would

\section{UK scientists under pressure to please}

\section{London}

One in three UK scientists working in government or recently privatized laboratories has been asked to alter research findings, according to a survey by a trade union that represents governmentemployed researchers.

Thirty per cent of respondents had been asked to modify their conclusions or advice. Reasons given were: to suit the customer's preferred outcome (17 per cent); to obtain further contracts ( 10 per cent); and to prevent publication ( 3 per cent).

The Institute of Professionals, Managers and Specialists (IPMS), which represents scientists in government departments, research councils and private companies, surveyed over 500 respondents from a range of employers.

An IPMS spokesperson said that the findings were "clearly significant at a time when the independence of scientists, both in and out of government, is increasingly being questioned".

Natasha Loder 
not write about it unless he did so. Czerkas agreed to this, says Sloan.

Meanwhile, Czerkas was working on a paper about the fossil that he hoped to publish in a major journal. Last summer, the plan was to publish the manuscript naming the specimen, with the National Geographic article following on its heels.

Although he does not hold a university degree, Czerkas says that he is widely respected in the scientific community for helping major museums create dinosaur displays. These contacts led him to his collaborators: Philip Currie, a palaeontologist at the Royal Tyrrell Museum of Palaeontology in Canada who has close links to China; Xu, who Currie recruited to the project; and palaeontologist Timothy Rowe, who has a laboratory at the University of Texas that scans specimens.

According to Rowe, by early August his laboratory had found problems with the fossil - in particular the added tail and questions relating to reconstructed leg bones. Rowe described the problems to Czerkas and Currie at a meeting in his laboratory.

Currie was in Argentina and unavailable for comment last week, but has been quoted in newspaper articles as saying that the whole affair is deeply embarrassing.

Czerkas finally agreed to modify the manuscript to address concerns, says Rowe, and the paper was sent to Nature, where it was rejected. With National Geographic's September printing deadline approaching, Czerkas sent the manuscript to Science, which sent it out for peer review. Two reviewers rejected it in the first week of September.

Suggesting the possibility that "the specimen was smuggled out of China and illegally purchased", one reviewer suggested that the specimen had been "doctored" by its unknown collectors "to enhance its value". He or she also commented that the specimen should be returned to China before being considered for publication.

Czerkas, the lead author, never fully informed National Geographic about the details of those rejections, says Sloan. National Geographiclearnt of Science's rejection shortly after its deadline for the November issue.

In October, National Geographic held a news conference to highlight its November issue, unveil the fossil and announce that its repatriation to China had been agreed.

But according to $\mathrm{Xu}$, Czerkas wanted the fossil to stay in the Utah museum for up to five years before sending it back. He says that Czerkas also sought potentially valuable casts of other Chinese dinosaurs and scientific exchanges in return for the fossil.

$\mathrm{Xu}$ says that he has since been negotiating with Czerkas to get the fossil returned immediately, as his superiors desire. He and Sloan say that last month, after newspaper reports had questioned the fossil's authenticity, Czerkas dropped the display demands.
Rowe withdrew from the project in early January, upset that Czerkas hadn't told National Geographic earlier about the fossil's composite nature and other issues.

Last week, Slade flew to Washington, picked up the fossil at the National Geographic and returned it to Utah. He says that the fossil is undergoing further studies and that an attempt will be made to publish the findings in another journal. He added that the patrons - who he declined to identify - have yet to transfer ownership of the fossil to the Blanding museum.

Xu may bring a similar fossil to Washington for independent comparison with Czerkas's specimen. Czerkas may then report the findings to a palaeontology meeting in March at the Graves Museum in Florida.

Czerkas says that he will return the fossil to China this spring, possibly at the June meeting of the International Society of Avian Paleontology in Beijing.

\section{The biggest, wildest fossil market in the west}

\section{Tucson, Arizona}

The Gem, Mineral and Fossil Showcase of Tucson, a city-wide street fair of international artefacts, is a major marketplace for fossils, many of which, some claim, have been smuggled out of China and other countries.

Chinese bird fossils from the early Cretaceous that have yet to be described, ancient skulls of rhino and ivory-tusked elephant, and dinosaur eggs were all on sale at the annual two-week event that ended last week.

Some of the dealers selling Chinese fossils say they have documents showing they were legally exported. But US and Chinese scientists say the papers are irrelevant, as the specimens are Chinese cultural treasures.

US customs officials say that the importation, possession and sale of a smuggled specimen may violate various federal laws. But an in-depth legal analysis of each case is needed to determine if a criminal offense was committed, says Customs Special Agent Lisa Fairchild in Washington DC.

About 3,000 dealers mostly selling gems and minerals - sell their wares in hotel rooms, on patches of ground and in huge tents. Dinosaur eggs and rhino skulls could be found among some of the 24 individually operated shows in Tucson, but this year most of the questionable Chinese fossils were being

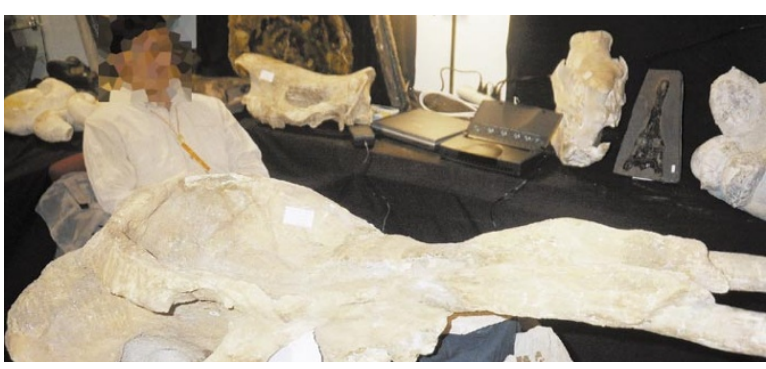

Happy hunting ground: A fossil elephant skull, for sale in Tucson.

sold at a show held in a converted hotel.

Chinese fossils large and small were displayed throughout the hotel. One room contained boxes of dozens of dinosaur eggs stacked like eggs in a supermarket.

It was in this setting that that dinosaur enthusiast Stephen Czerkas organized the purchase last year of the controversial bird fossil that found its way into the National Geographic magazine last November (see main story).

Czerkas refuses to say who sold the fossil for $\$ 80,000$. He says that, after he had found it, a patron went to Tucson to buy the fossil for the small Dinosaur Museum in Blanding, Utah. But the museum's main patron, Dale Slade, says that Czerkas went to Tucson and bought the fossil himself.

Timothy Rowe, a

University of Texas palaeontologist who has analysed the fossil, visited Tucson this year to investigate its source. While there he met dealers such as Zhouping Guo, a watercompany geologist who runs the company Sin-Am Bridge out of his home near San Diego, California.

Rowe says that Zhouping knows Czerkas and that during Rowe's visit he produced three Chinese bird fossils that appeared to be species not yet described in the scientific literature.

Zhouping denies selling Czerkas the fossil. He says that he has documents from a Chinese museum proving his specimens were legally exported for scientific exchange, although he refused Nature's request to inspect the documents.

Martin Zinn, who ran the show that included independent firms like Sin-Am Bridge, says he prohibits dealers from selling smuggled or illegal goods, that Sin-Am insisted its specimens were properly documented, and that all was "normal".

A spokeswoman for the Metropolitan Tucson Convention and Visitors Bureau, which organizes the showcase, says the organization knew nothing of illegal sales and was not responsible for independent dealers. 